\title{
Association of Freshman Retention Rates with Instructional Expenditure and Residential Status : A Case Study for Large Public Colleges Sadjad Pariafsai*1, David Dalenberg², Christopher Ellison², Lucas Johnson ${ }^{3}$, Fatemeh Pariafsai ${ }^{4}$ \\ ${ }^{1}$ Faculty of Engineering, Islamic Azad University, Tehran, Tehran, Iran \\ ${ }^{2}$ Department of Statistics, Texas A\&M University, College Station, Texas, USA \\ ${ }^{3}$ Department of Mathematics, Texas A\&M University, College Station, Texas, USA \\ ${ }^{4}$ Department of Construction Science, Texas A\&M University, College Station, Texas, USA \\ Email: st_s_pariafsai@azad.ac.ir
}

\begin{abstract}
Article Info

Volume 8, Issue 3

Retention is a key indicator of institutional effectiveness in education research.

Page Number : $11-21$

Retaining full-time freshman students has been a long-standing problem for institutions of higher education. Overall, $40 \%$ of U.S. college students leave college among which the majority are freshman students. About $30 \%$ of freshman students

Publication Issue :

May-June-2021

\section{Article History}

Accepted : 02 May 2021

Published: 10 May 2021 drop out before their sophomore year of college. The primary causes for leaving college include financial pressure, falling behind in classwork, lack of social connections, and loss of family support. Higher educational institutions need to understand the dynamic between different expenditures and freshman retention rates to responsibly and strategically allocate funds to what will best support institutional success. This study investigates how freshman retention rates at large public colleges are associated with instructional expenditures and residential status. Findings of this study indicate that regarding freshman retention at large public colleges, spending more money on instruction goes further for residential colleges compared to non-residential ones. In other words, for most levels of instructional expenditure, residential colleges have higher freshman retention rates than nonresidential colleges. Findings of this study can assist higher education institutions in directing their efforts toward what will best support institutional success.
\end{abstract}

Keywords: Beta regression, freshman retention rate, instructional expenditure, large public colleges, residential status

\section{INTRODUCTION}

Retention refers to institutional factors related to keeping students enrolled in an educational institution (Lenhardt 2017), it is a crucial sign of educational success, (Henderson et al. 2016) and a key indicator of institutional quality and effectiveness in education research (Pike and Graunke 2015). Not only does retention maintain revenue, but it also costs less than recruiting new students (Schuette 2019). Retaining full-time freshman students is a problem for institutions of higher education (Turner and Thompson 2014). Overall, 40\% of U.S. college students leave college among which the majority are 
freshman students. About 30\% of freshman students drop out before their sophomore year of college (Miller 2019). While persistence focuses on the role of student characteristics, retention concentrates on the role of students' on-campus experiences (Henderson et al. 2016). Studies that focus on the student experience often examine their interactions in academic and social environments as contributing factors of persistence and retention (Astin 1973; Astin 1977; Braxton et al. 2008; Chickering 1974; Pascarella and Smart 1991; Upcraft 1985). This branch of research examines the effects of specific academic and social programs and policies, such as residential living, learning communities, academic advising, and mentorship (Henderson et al. 2016). Robbins et al. (2009) found that utilization of services such as academic advising and recreational resources has the largest increases concerning freshmen retention. Marra et al. (2015) indicated social and academic integration factors significantly predict students' learning outcomes, especially their commitment to studies in their chosen field. Henderson et al. (2016) found that communal potential is a significant factor of students' social integration, which influences their decision to persist.

Key studies explored how institutional expenditures are related to student outcomes, including retention, persistence, and graduation (Clark et al. 2006; Gansemer-Topf and Schuh 2003; Ryan 2004; Webber and Ehrenberg 2010). Webber and Ehrenberg (2010) determined that funding allocations for student services and instruction positively impacted student retention. They reported that retention also increased when funding for instruction was reduced to increase funding for student services. Powell et al. (2012) and Gansemer-Topf and Schuh (2003) found that expenditures for instruction and academic support improved retention rates. Ryan's (2004) research revealed that expenditures on academic support and instruction positively impacted student retention. Lenhardt (2017) also indicated that expenditures for instruction, academic support, and student services significantly impact student retention. Webster and Showers (2011) focused on other institutional factors such as tuition, amount of student financial aid, faculty salaries, and student/teacher ratio as potential factors related to student retention. The researchers found that higher costs of tuition, amount of student financial aid, and faculty salaries have a positive correlation with student retention while student/teacher ratio has a negative correlation. Webster and Showers (2011) suggested that a lower student/teacher ratio indicated that smaller classes would increase student retention. However, Lenhardt (2017) revealed that student-to-faculty ratios did not significantly impact retention.

Student retention has been a long-standing issue for administrators in higher education. These educational leaders need to understand how instructional expenditures and freshman retention trends align. Understanding the dynamic between instructional expenditures and freshman retention will help them responsibly and strategically allocate funds to where they will best support institutional success, which includes student retention (Escamilla et al., 2018; Pariafsai, 2013, 2016a, 2016b, 2016c, 2016d, 2016e, 2016f, 2016g). This research aims to understand how freshman retention rates in large public colleges are associated with instructional expenditures and residential status. Based on the prior literature and the nature of the institutions the authors are studying, this study investigates the following questions:

1-1. Does the association between instructional expenditure per student and freshman to sophomore retention rate depend on residential status?

1-2. If so, is this a positive association for both residential and non-residential colleges?

2-1. Does the association between residential status and freshman to sophomore retention rate depend on instructional expenditure per student? 
2-2. If so, do residential colleges have higher retention rates?

\section{METHODS AND MATERIAL}

The data used for this study comes from two sources: the U.S. Department of Education's College Scorecard (U.S. Department of Education 2020), and the National Center for Education Statistics' Integrated Postsecondary Education Data System (IPEDS) (IESNCES 2020). The authors used the most recent data available, which consisted of the 2020 release of the College Scorecard data and the 2019-2020 IPEDS survey cycle. The response variable, freshman retention rate, is expressed as a proportion, which suggests using a beta-regression model with logit link (Ferrari and Cribari-Neto 2004). Beta regression is a technique that has been proposed for modeling data for which the observations are limited to the open interval $(0,1)$ (Ferrari and Cribari-Neto 2004; Smithson and Verkuilen 2006). In this study, Beta regression was used to evaluate the following hypotheses:

$\mathrm{H}_{0-1}$ : The association between instructional expenditure per student and freshman to sophomore retention rate does not depend on residential status and there is neither an association with residential nor non-residential colleges.

$\mathrm{H}_{\mathrm{a}-1}$ : The association between instructional expenditure per student and freshman to sophomore retention rate depends on residential status and it is a positive association for both residential and nonresidential colleges.

Ho-2: The association between residential status and freshman to sophomore retention rate does not depend on instructional expenditure per student, and residential colleges have the same retention rates as non-residential colleges.
$\mathrm{H}_{\mathrm{a}-2}$ : The association between residential status and freshman to sophomore retention rate depends on instructional expenditure per student, and residential colleges have higher retention rates.

The authors wanted to model the response primarily as a function of Carnegie's classification of institutions by size and residential status, and instructional expenditure per student. For this purpose, the Carnegie classification was restricted to whether an institution was "primarily non-residential," "primarily residential," or "highly residential." Since only 13 institutions were highly residential, the authors merged "primarily residential" and "highly residential" for this analysis, creating a fixed-effects categorical variable with two levels. The authors found that instructional expenditure per student was highly right-skewed, and chose to use the log-transform of instructional expenditure per student to provide a more normal distribution of values for this covariate. One key interest in this research was whether residential status impacted the association between freshman retention rate and instructional expenditure per student, so the authors included a term for the impact of residential status on the slope of the instructional expenditure covariate.

Additionally, the authors believed that other covariates might impact the freshman retention rate, including student-to-faculty ratio, admission rate, SAT average, percentage of underrepresented minority undergraduates, percentage of firstgeneration undergraduate students, percentage of female undergraduates, and percentage of undergraduates receiving Pell Grants. The authors wanted to control for these covariates, but because they were not of primary interest, the authors did not consider interactions between these secondary covariates and the residential status factor or the expenditure covariate. 
The authors analyzed the covariates for pairwise collinearity and collective multicollinearity, first examining pairwise scatterplots. As shown in the scatterplot matrix for pairwise collinearity (Figure 1), most covariate pairs do not raise concerns, showing minimal or moderate collinearity. However, the percentage of Pell Grant recipients, percentage of first-generation undergraduate students, and percentage of underrepresented minority undergraduates seem to be pairwise correlated.

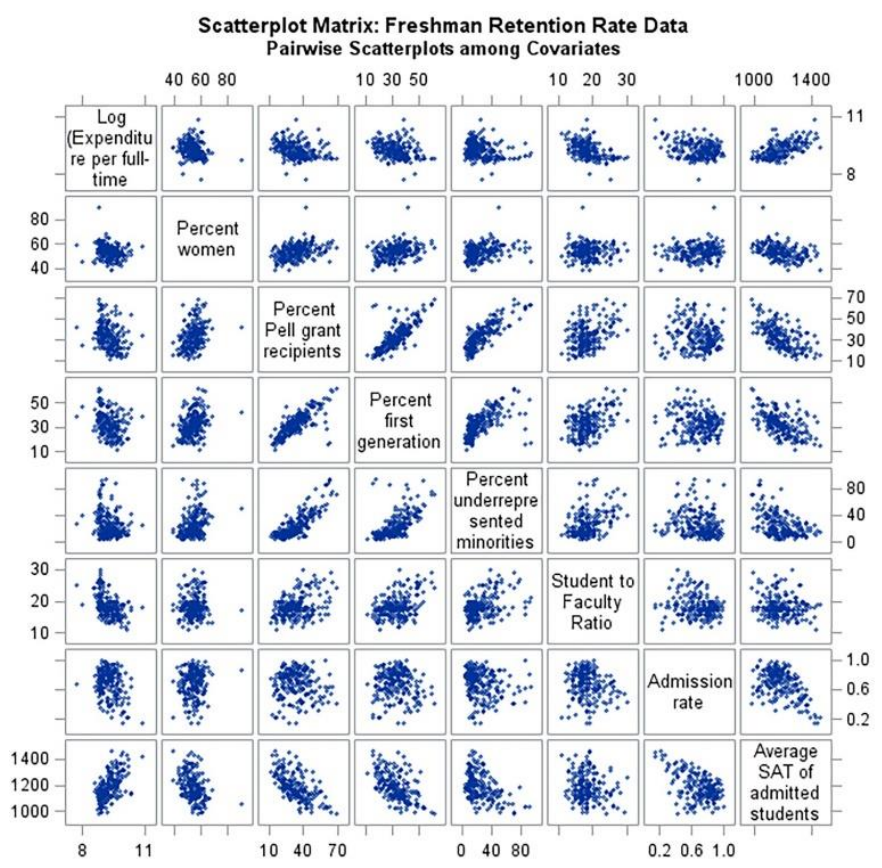

Figure 1. Scatterplot matrix for pairwise collinearity assessment of model covariates

The pairwise Pearson correlation coefficient for the percentage of Pell Grant recipients and percentage of first-generation undergraduates was 0.762; for the percentage of Pell Grant recipients and percentage of underrepresented minority undergraduates, it was 0.821; for the percentage of Pell Grant recipients and SAT scores it was -0.629 , and for the percentage of first-generation undergraduates and percentage of underrepresented minority undergraduates, it was 0.601. All other pairwise Pearson correlation coefficients among the covariates had magnitude less than 0.6. The authors also examined the variance inflation factors (VIF) among the covariates and found that the percentage of Pell Grant recipients had a VIF of 6.26, while all other VIFs were less than 5 (the threshold for indicating a multicollinearity problem). The authors removed the percentage of Pell Grant recipients from the model, and among the remaining covariates, all VIFs were less than 5 . The authors thus excluded percentage of Pell Grant recipients from the model; any information it provided to the model was adequately captured by other model covariates.

For variable selection, the authors fit a betaregression model to the data and found that the slope for percentage of female undergraduates was not significantly different from zero $(\alpha=0.05)$, and removed the covariate from the model. For the resulting model, all remaining terms were significant $(\alpha=0.05)$. The final mean model is:

Logit $\left(p_{i j}\right)=\beta_{0}+\alpha_{i}+\left(\beta_{1}+\gamma_{i}\right) x_{1 j}+\beta_{2 x} 2_{i j}+\beta_{3 x} 3_{i j}+\beta_{4 x} 4_{i j}+$ $\beta_{5} \times 5_{i j}+\beta_{6} \times 6_{i j}$

where the model variables are defined as follows:

\section{Indexes}

$i=1,2$ Carnegie Residency Classification

( $i=1$ for primarily non-residential, $i=2$ for primarily/highly residential)

$j=1, \ldots, \mathrm{n}_{i}$ for the institution

\section{Response Variable}

$p_{i j} \quad$ Freshman retention rate (the proportion of firsttime, full-time freshmen who return for their sophomore year)

\section{Primary Factor and Covariate}

$\beta_{0} \quad$ is the overall intercept term

$\alpha_{i} \quad$ is the intercept effect of residential type $i$

$\mathrm{x} 1_{\mathrm{ij}}$ is LOG(expenditure per student) for institution $j$ of residency type $i$ 
$\beta_{1} \quad$ is the overall slope associated with

LOG(expenditure)

$\gamma_{i}$ is the effect of residency type $i$ on the slope of

LOG(expenditure)

\section{Additional Covariates}

$\mathrm{x} 2_{\mathrm{ij}}$ is the student-faculty ratio

$\beta_{2}$ is the slope associated with $\mathrm{x} 2_{\mathrm{ij}}$

$\mathrm{x} 3_{\mathrm{ij}}$ is the admission rate

$\beta_{3}$ is the slope associated with $\mathrm{x} 3_{\mathrm{ij}}$

$\mathrm{x} 4_{\mathrm{ij}}$ is the average SAT score

$\beta_{4} \quad$ is the slope associated with $\mathrm{x} 4_{\mathrm{ij}}$

$\mathrm{x} 5_{\mathrm{ij}}$ is the percentage of undergraduate first-

generation college students

$\beta_{5} \quad$ is the slope associated with $\times 5_{\mathrm{ij}}$

$\mathrm{x} 6_{\mathrm{ij}}$ is the percentage of undergraduates that are underrepresented minorities

$\beta_{6} \quad$ is the slope associated with $\times 6_{i j}$

The authors noted that 14 of the institutions did not report SAT averages. Most (11) of these institutions were "predominantly non-residential," but no other clear pattern regarding why the values were missing was apparent. The authors believed the small number of missing values (5.0\% of the total observations) would not greatly impact the study results.

Using the GLIMMIX procedure in SAS to fit the model to the data, the authors obtained the parameter estimates in Table 1, along with associated p-values for testing whether those estimates were significantly different from zero. None were non-significant at $\alpha=0.05$.

Table 1. Model parameter estimates, including $\mathrm{p}^{-}$ values

\begin{tabular}{|l|l|l|l|l|l|l|}
\hline \multicolumn{7}{|c|}{ Parameter Estimates } \\
\hline \multirow{4}{*}{ Effect } & Carnegi & e & Stan & & t V & \\
& resident & Esti & dard & D & alu & Pr \\
& ial & mate & Erro & F & e & $>|t|$ \\
& classific & & r & & & \\
\hline
\end{tabular}

\begin{tabular}{|c|c|c|c|c|c|c|}
\hline & ation & & & & & \\
\hline Intercept & & $\begin{array}{l}- \\
5.60 \\
45\end{array}$ & $\begin{array}{l}0.83 \\
24\end{array}$ & $\begin{array}{l}1 \\
9 \\
6\end{array}$ & $\begin{array}{l}- \\
6.7 \\
3\end{array}$ & $\begin{array}{l}<.0 \\
001\end{array}$ \\
\hline $\begin{array}{l}\text { Log(Expendit } \\
\text { ure per } \\
\text { Student) }\end{array}$ & & $\begin{array}{l}0.37 \\
7\end{array}$ & $\begin{array}{l}0.08 \\
989\end{array}$ & $\begin{array}{l}1 \\
9 \\
6\end{array}$ & $\begin{array}{l}4.1 \\
9\end{array}$ & $\begin{array}{l}<.0 \\
001\end{array}$ \\
\hline $\begin{array}{l}\text { Carnegie } \\
\text { Size/Setting }\end{array}$ & $\begin{array}{l}\text { Non- } \\
\text { Residen } \\
\text { tial }\end{array}$ & $\begin{array}{l}3.11 \\
87\end{array}$ & $\begin{array}{l}1.01 \\
19\end{array}$ & $\begin{array}{l}1 \\
9 \\
6\end{array}$ & $\begin{array}{l}3.0 \\
8\end{array}$ & $\begin{array}{l}0.0 \\
024\end{array}$ \\
\hline $\begin{array}{l}\text { Carnegie } \\
\text { Size/Setting }\end{array}$ & $\begin{array}{l}\text { Residen } \\
\text { tial }\end{array}$ & 0 & . & · & . & . \\
\hline $\begin{array}{l}\text { Log(Expendit } \\
\text { ure)xCarnegie } \\
\text { Interaction }\end{array}$ & $\begin{array}{l}\text { Non- } \\
\text { Residen } \\
\text { tial }\end{array}$ & $\begin{array}{l}- \\
0.34 \\
74\end{array}$ & $\begin{array}{l}0.10 \\
97\end{array}$ & $\begin{array}{l}1 \\
9 \\
6\end{array}$ & $\begin{array}{l}- \\
3.1 \\
7\end{array}$ & $\begin{array}{l}0.0 \\
018\end{array}$ \\
\hline $\begin{array}{l}\text { Log(Expendit } \\
\text { ure)xCarnegie } \\
\text { Interaction }\end{array}$ & $\begin{array}{l}\text { Residen } \\
\text { tial }\end{array}$ & 0 & . & . & . & . \\
\hline $\begin{array}{l}\text { Student- } \\
\text { Faculty Ratio }\end{array}$ & & $\begin{array}{l}0.02 \\
273\end{array}$ & $\begin{array}{l}0.00 \\
7351\end{array}$ & $\begin{array}{l}1 \\
9 \\
6\end{array}$ & $\begin{array}{l}3.0 \\
9\end{array}$ & $\begin{array}{l}0.0 \\
023\end{array}$ \\
\hline $\begin{array}{l}\text { Admission } \\
\text { Rate }\end{array}$ & & $\begin{array}{l}- \\
1.00 \\
6\end{array}$ & $\begin{array}{l}0.14 \\
74\end{array}$ & $\begin{array}{l}1 \\
9 \\
6\end{array}$ & $\begin{array}{l}- \\
6.8 \\
2\end{array}$ & $\begin{array}{l}<.0 \\
001\end{array}$ \\
\hline $\begin{array}{l}\text { Average SAT } \\
\text { Score }\end{array}$ & & $\begin{array}{l}0.00 \\
3498\end{array}$ & $\begin{array}{l}0.00 \\
0366\end{array}$ & $\begin{array}{l}1 \\
9 \\
6\end{array}$ & $\begin{array}{l}9.5 \\
5\end{array}$ & $\begin{array}{l}<.0 \\
001\end{array}$ \\
\hline $\begin{array}{l}\text { Percent } \\
\text { Underreprese } \\
\text { nted Minority } \\
\text { Undergraduat } \\
\text { es }\end{array}$ & & $\begin{array}{l}0.00 \\
4071\end{array}$ & $\begin{array}{l}0.00 \\
1541\end{array}$ & $\begin{array}{l}1 \\
9 \\
6\end{array}$ & $\begin{array}{l}2.6 \\
4\end{array}$ & $\begin{array}{l}0.0 \\
089\end{array}$ \\
\hline $\begin{array}{l}\text { Percent First- } \\
\text { Generation } \\
\text { Undergraduat } \\
\text { es }\end{array}$ & & $\begin{array}{l}- \\
0.00 \\
733\end{array}$ & $\begin{array}{l}0.00 \\
3639\end{array}$ & $\begin{array}{l}1 \\
9 \\
6\end{array}$ & $\begin{array}{l}- \\
2.0 \\
1\end{array}$ & $\begin{array}{l}0.0 \\
454\end{array}$ \\
\hline Scale & & $\begin{array}{l}96.7 \\
97\end{array}$ & $\begin{array}{l}9.54 \\
55\end{array}$ & & & . \\
\hline
\end{tabular}

The estimated slope for the log (expenditure per student) covariate is 0.3770 for primarily/highly residential institutions, and 0.0296 for primarily nonresidential institutions. For example, if a primarily residential institution increases its expenditure per student by $25 \%$, then the log (expenditure per student) 
would increase by 0.2231 , and if all other covariates are held constant, the model predicts that the logit of freshman retention would increase by $0.2231 \times 0.3770=0.0841$. That is, the odds of freshman retention would increase by approximately $8.77 \%$. Similarly, for a non-residential institution, the increase in odds of freshman retention would be approximately $0.66 \%$. Thus for a $25 \%$ increase in expenditure per student, with all other covariates held constant, a primarily residential institution with $40 \%$ freshman retention would see an increase to $42 \%$, and a similar institution with $80 \%$ freshman retention would see an increase to $81.3 \%$. For similar primarily non-residential institutions, the $25 \%$ increase in expenditure per student would see the $40 \%$ retention rate rise to $40.16 \%$, and the $80 \%$ retention rate would rise to $80.1 \%$.

The authors noted that the Pearson Chi-Square/DF value was 1.06 , indicating a good fit of the model to the data. The authors also calculated the pseudo- $\mathrm{R}^{2}$ statistics, Pearson's correlation coefficient, comparing the predicted logit $\left(p_{i j}\right)$ values to the logit-transformed observed responses, and obtained a value of 0.912 , also suggesting a good fit, in the logit scale.

Even though there is no assumption of normally distributed errors for beta regression, the authors examined the studentized residual plots to rule out any gross abnormalities that might require further investigation. The studentized residuals in Figure 2 reveal neither severe outliers nor an unusual distribution.
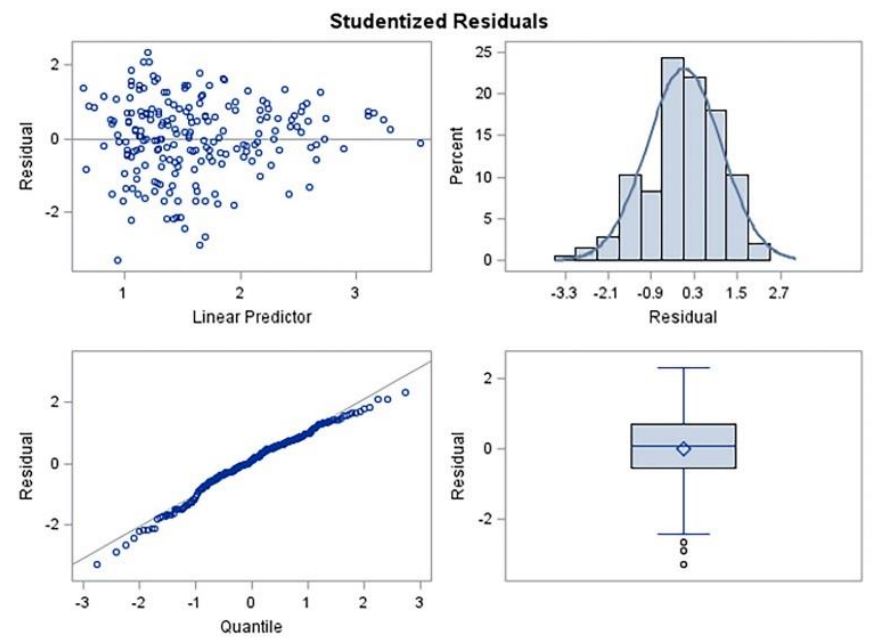

Figure 2. Studentized residual plots

The authors also plotted the studentized residuals against the predicted response values in logit scale and against the covariates in Figures 3 and 4 respectively. No patterns or extreme outliers were detected.

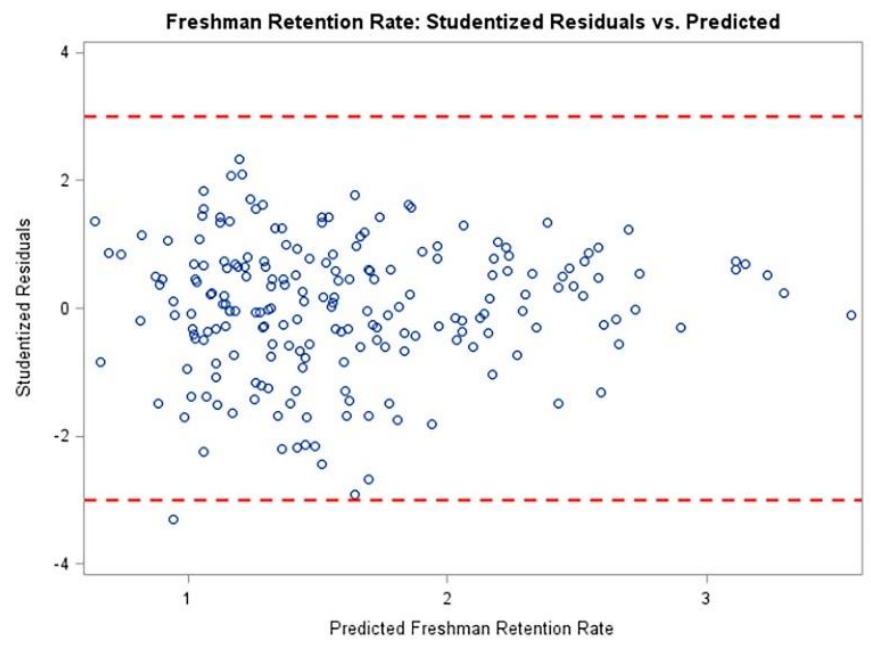

Figure 3. Studentized residuals vs predicted response, in logit scale

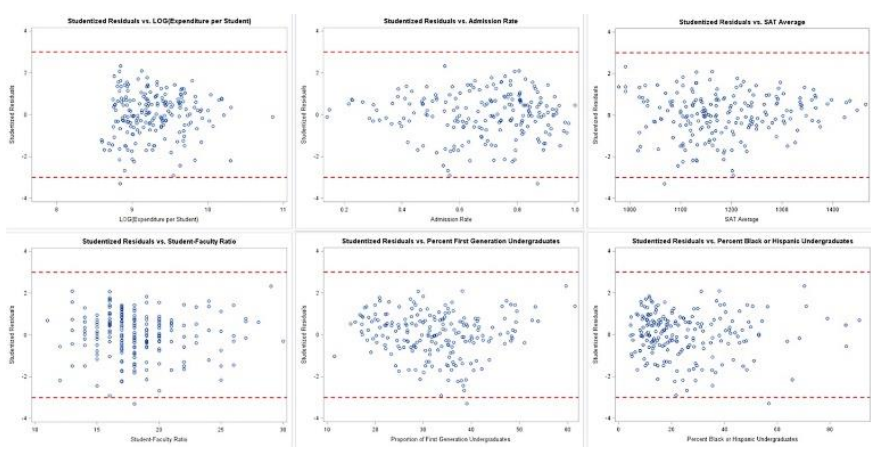

Figure 4. Studentized Residuals plotted against each covariate 


\section{III.RESULTS AND DISCUSSION}

After going through the variable selection process to arrive at the final model, the first step was to convert from the log-odds scale to the mean scale, since the authors are primarily interested in interpreting the effects in terms of the conditional mean of the retention rate. To do this, the authors used average marginal effects (AMEs). The average marginal effects for the covariates are displayed in Table 2. Because all of the covariates are continuous variables, the authors had the option to either look at these AMEs in terms of the instantaneous rate of change, or the authors could interpret them in terms of discrete changes. The authors opted for discrete changes, viewing the effects in terms of average differences between the covariate of interest held at 1 standard deviation below the mean to 1 standard deviation above the mean. These effects are in Table 2 along with their 95\% confidence intervals.

Table 2. AMEs of Covariates: 1 SD below Mean to 1 SD above Mean

\begin{tabular}{|l|l|l|l|}
\hline Covariate & AME & $\begin{array}{l}\text { Lower } \\
\text { 95\% } \\
\text { C.I. }\end{array}$ & $\begin{array}{l}\text { Upper } \\
\text { 95\% } \\
\text { C.I. }\end{array}$ \\
\hline Admission Rate & -0.053 & -0.068 & -0.038 \\
\hline $\begin{array}{l}\text { Under-represented } \\
\text { Minorities }\end{array}$ & 0.020 & 0.005 & 0.034 \\
\hline First Generation & -0.019 & -0.038 & -0.001 \\
\hline SAT Average & 0.100 & 0.080 & 0.120 \\
\hline $\begin{array}{l}\text { Student to Faculty } \\
\text { Ratio }\end{array}$ & 0.022 & 0.008 & 0.036 \\
\hline
\end{tabular}

To put this into context, consider the marginal effect of the admission rate. The mean of this variable in the sample is .68, and the standard deviation is .19 . So, the average difference in predicted retention rate between colleges whose admission rate is .49 and colleges whose admission rate is .87 is -.053 , meaning that the higher the admission rate, the lower the predicted retention rate.

While the AMEs for the covariates provide useful information, the focus of the study is on the interaction between instructional expenditure per student and residential status. The authors again looked to marginal effects to interpret this interaction, but the authors then needed to take the differences in those effects to test whether or not there is evidence for interaction on the mean scale.

First, the authors examined the interaction in terms of how the AME (again measured from 1 standard deviation above the mean to 1 standard deviation below the mean) of instructional expenditure on predicted retention rate changes depending on whether the college is residential or non-residential. Figure 5 shows that while the AME of instructional expenditure appears to be relatively flat when colleges are non-residential (AME of .003), there is a constant upward trend when colleges are residential (AME of .042). The difference between these effects (the second difference) is statistically significant at the $95 \%$ confidence level (see Tables 3 and 4). Therefore, the authors have evidence to support the alternative hypothesis that the effect of instructional expenditure per student does depend on the residential status of the college.

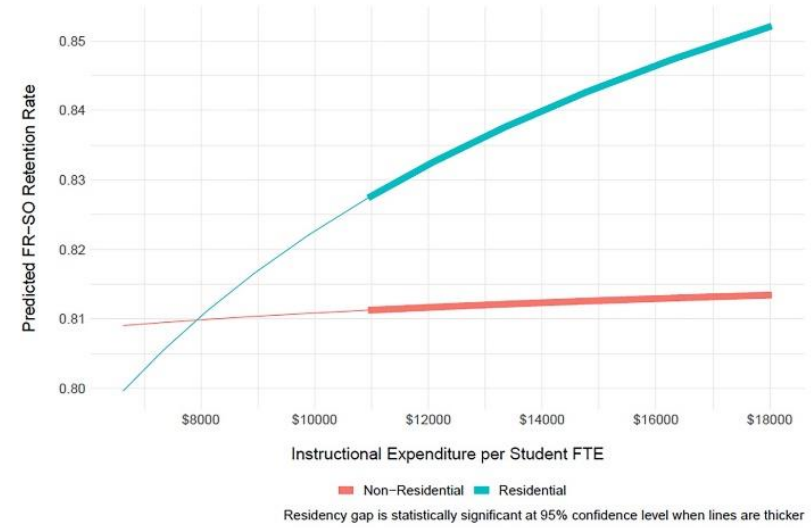

Figure 5. Predicted FR-SO Retention Rates by Residential Status and Instructional Expenditure per Student 
Table 3. AMEs of Main Explanatory Variables

\begin{tabular}{|c|c|c|c|c|c|}
\hline $\begin{array}{l}\text { AME } \\
\text { of } \\
\text { Intere } \\
\text { st }\end{array}$ & $\begin{array}{l}\log (\operatorname{Ex} \\
\text { p.) }\end{array}$ & $\begin{array}{l}\text { Res. } \\
\text { Status }\end{array}$ & $\begin{array}{l}\mathrm{AM} \\
\mathrm{E}\end{array}$ & $\begin{array}{l}\text { Low } \\
\text { er } \\
95 \% \\
\text { C.I. }\end{array}$ & $\begin{array}{l}\text { Upp } \\
\text { er } \\
95 \% \\
\text { C.I. }\end{array}$ \\
\hline $\begin{array}{l}\text { Non- } \\
\text { Res. - } \\
\text { Res. }\end{array}$ & 8.8 & & 0.009 & -0.009 & 0.028 \\
\hline $\begin{array}{l}\text { Non- } \\
\text { Res. - } \\
\text { Res. }\end{array}$ & 8.9 & & 0.004 & -0.012 & 0.021 \\
\hline $\begin{array}{l}\text { Non- } \\
\text { Res. - } \\
\text { Res. }\end{array}$ & 9.0 & & $\begin{array}{l}- \\
0.001\end{array}$ & -0.016 & 0.013 \\
\hline $\begin{array}{l}\text { Non- } \\
\text { Res. - } \\
\text { Res. }\end{array}$ & 9.1 & & $\begin{array}{l}- \\
0.006\end{array}$ & -0.020 & 0.007 \\
\hline $\begin{array}{l}\text { Non- } \\
\text { Res. - } \\
\text { Res. }\end{array}$ & 9.2 & & $\begin{array}{l}- \\
0.011\end{array}$ & -0.024 & 0.002 \\
\hline $\begin{array}{l}\text { Non- } \\
\text { Res. - } \\
\text { Res. }\end{array}$ & 9.3 & & $\begin{array}{l}- \\
0.016\end{array}$ & -0.029 & -0.003 \\
\hline $\begin{array}{l}\text { Non- } \\
\text { Res. - } \\
\text { Res. }\end{array}$ & 9.4 & & $\begin{array}{l}- \\
0.021\end{array}$ & -0.035 & -0.007 \\
\hline $\begin{array}{l}\text { Non- } \\
\text { Res. - } \\
\text { Res. }\end{array}$ & 9.5 & & $\begin{array}{l}- \\
0.026\end{array}$ & -0.041 & -0.010 \\
\hline $\begin{array}{l}\text { Non- } \\
\text { Res. - } \\
\text { Res. }\end{array}$ & 9.6 & & $\begin{array}{l}- \\
0.030\end{array}$ & -0.047 & -0.013 \\
\hline Non- & 9.7 & & - & -0.053 & -0.015 \\
\hline
\end{tabular}

\begin{tabular}{|l|l|l|l|l|l|}
\hline $\begin{array}{l}\text { Res. - } \\
\text { Res. }\end{array}$ & & & 0.034 & & \\
\hline $\begin{array}{l}\text { Non- } \\
\text { Res. - } \\
\text { Res. }\end{array}$ & 9.8 & & - & -0.060 & -0.018 \\
\hline $\begin{array}{l}\text { Log(Ex } \\
\text { p.) }\end{array}$ & & $\begin{array}{l}\text { Resid } \\
\text { ential }\end{array}$ & 0.042 & 0.023 & 0.061 \\
\hline $\begin{array}{l}\text { Log(Ex } \\
\text { p.) }\end{array}$ & $\begin{array}{l}\text { Non- } \\
\text { Reside } \\
\text { ntial }\end{array}$ & 0.003 & -0.017 & 0.024 \\
\hline
\end{tabular}

Table 4. Second Differences for Testing Interaction Effect

\begin{tabular}{|l|l|l|l|l|}
\hline AME & Comparison & $\begin{array}{l}\text { 2nd } \\
\text { Diff. }\end{array}$ & $\begin{array}{l}\text { Lower } \\
\text { 95\% } \\
\text { C.I. }\end{array}$ & $\begin{array}{l}\text { Upper } \\
\text { 95\% } \\
\text { C.I. }\end{array}$ \\
\hline Res. Gap & $\begin{array}{l}\text { Log(Exp.) at } \\
\text { 9 vs. 9.8 }\end{array}$ & 0.037 & 0.014 & 0.061 \\
\hline Res. Gap & $\begin{array}{l}\text { Log(Exp.) at } \\
\text { 9.1 vs. 9.7 }\end{array}$ & 0.028 & 0.010 & 0.046 \\
\hline Res. Gap & $\begin{array}{l}\text { Log(Exp.) at } \\
\text { 9.2 vs. 9.6 }\end{array}$ & 0.019 & 0.007 & 0.031 \\
\hline Res. Gap & $\begin{array}{l}\text { Log(Exp.) at } \\
\text { 9.3 vs. 9.5 }\end{array}$ & 0.009 & 0.003 & 0.015 \\
\hline Log(Exp.) & $\begin{array}{l}\text { Residential } \\
\text { vs. Non- } \\
\text { Residential }\end{array}$ & 0.038 & 0.014 & 0.062 \\
\hline
\end{tabular}

Looking to the other side of the interaction, the authors now needed to test if the difference in retention rate between residential and non-residential colleges depends on the amount of instructional expenditure. This process was a bit more subjective, as there are many second differences that the authors could test. Here, the authors decided to test the 
following pairs of differences between residential colleges and non-residential colleges: log (instructional expenditures) at 9 vs. 9.8, 9.1 vs. 9.7, 9.2 vs. 9.6, and 9.3 vs. 9.5. It turns out that all of these second differences are statistically significant at the $95 \%$ confidence level, thus providing evidence for this side of the interaction as well (see Tables 3 and 4). Indeed, the authors see visual evidence of this side of the interaction, as the gap between residential and nonresidential colleges grows increasingly wide as more is spent on instructional expenses. At the upper end of instructional expenditure, residential colleges have about a 4 percentage point higher predicted retention rate than non-residential colleges.

\section{IV.CONCLUSION}

The findings of this study indicate that in terms of retaining freshmen at large public colleges, spending more money on instruction goes further for residential colleges compared to non-residential ones. When comparing residential colleges, instructional expenditure is an important variable to account for, and, for most levels of instructional expenditure, residential colleges have higher retention rates than non-residential ones. However, the gaps are not huge. In other words, there is no evidence that large public residential colleges have a superior advantage in retaining their freshmen as compared to their nonresidential counterparts.

Because of the existing gaps, there might be certain instructional budget lines at residential colleges that, when properly funded, help students to stay engaged, focused, and motivated to continue their academic careers after that first, perhaps very difficult, year. It is also necessary to clarify that this is purely an associational study, as the authors make no claims of causality.

Future research is required to take a deeper dive into the reasons that large public residential colleges make better use of their instructional expenses than those that are non-residential. There is space for rich qualitative work in this area, as researchers can investigate specifically how instructional expenditures are calculated and what precisely goes into this calculation for different colleges. Another area of research should test for the presence of this interaction effect at different types of colleges, such as large or small private institutions.

\section{ACKNOWLEDGMENTS}

The authors thank Dr. Derya Akleman for sharing her invaluable professional opinions on this research.

\section{REFERENCES}

[1]. Astin, A. W. (1973). The Impact of Dormitory Living on Students. Educational record.

[2]. Astin, A. W. (1977). Four Critical Years. Effects of College on Beliefs, Attitudes, and Knowledge.

[3]. Braxton, J. M., Jones, W. A., Hirschy, A. S., \& Hartley III, H. V. (2008). The role of active learning in college student persistence. New directions for teaching and learning, 2008(115), 71-83.

[4]. Brundage, I. (2017). Comparison of Factors Contributing to the Retention of Minority Students at Two Different Types of Institutions: A Predominantly White Institution (PWI) and Hispanic Serving Institution (HSI). Florida Gulf Coast University,

[5]. Chickering, A. W. (1974). Commuting versus resident students: Jossey-Bass.

[6]. Clark, M. A., Brooks, M., Lee, S. M., Daley, L. P., Crawford, Y., \& Maxis, S. (2006). Factors influencing the educational success of minority pre-service educators. Journal of College Student Retention: Research, Theory \& Practice, 8(1), 121-135. 
[7]. Escamilla, E. F., Ostadalimakhmalbaf, M., Pariafsai, F., Gragera, C., \& Alizadeh, M. N. (2018). Enrollment, Retention, and Graduation patterns of Higher-Education Construction Science Students at Texas A\&M University: A Comparative Study. The Professional Constructor Journal of the American Institute of Constructors, 43(1), 48-61.

[8]. Escamilla, E. F., Ostadalimakhmalbaf, M., Pariafsai, F., Gragera, C., \& Alizadeh, M. N. (2018). Enrollment, Retention, and Graduation patterns of Higher-Education Construction Science Students at Texas A\&M University: A Comparative Study. The Professional Constructor Journal of the American Institute of Constructors, 43(1), 48-61.

[9]. Ferrari, S., \& Cribari-Neto, F. (2004). Beta regression for modelling rates and proportions. Journal of applied statistics, 31(7), 799-815.

[10]. Gansemer-Topf, A. M., \& Schuh, J. H. (2003). Instruction and academic support expenditures: An investment in retention and graduation. Journal of College Student Retention: Research, Theory \& Practice, 5(2), 135-145.

[11]. Henderson, S. M., Burton-Krieger, M. C., \& McClendon, M. E. (2016). A Communal Approach to Retention: Birmingham Southern College.

[12]. IES-NCES. (2020). IPEDS Integrated Postsecondary Education Data System. Retrieved from https://nces.ed.gov/ipeds/usethe-data

[13]. Lenhardt, J. L. (2017). A comparative trend analysis of institutional variables and retention rates in publicly funded institutions. Capella University,

[14]. Marra, R. M., Tsai, C.-L., Bogue, B., \& Pytel, J. L. (2015). Alternative pathways to engineering success-using academic and social integration to understand two-year engineering student success. American Journal of Engineering Education (AJEE), 6(2), 69-84.
[15]. Miller, C. (2019). College Dropout Rates. Retrieved from https://educationdata.org/college-dropout-rates

[16]. Pariafsai, F. (2013). Management and Construction Equipment Vol. 1. Tehran, Iran: Adabestan.

[17]. Pariafsai, F. (2016a). Effectiveness of a virtual project-based simulation game in construction education. International Journal of Scientific Research in Science, Engineering and Technology (IJSRSET), 2(5), 377-393.

[18]. Pariafsai, F. (2016b). Effectiveness of Virtual Project-Based Simulation Games at Different levels of Construction Education. Paper presented at the 5th International conference on Science \& Engineering, Paris, France.

[19]. Pariafsai, F. (2016c). Project-Based Simulation Game: an Effective Learning Tool for Students with Limited Prior Education in Construction. Paper presented at the 3rd International Conference on New Research Achievements in Civil, Architecture \& Urban Management, Tehran, Iran, September 16th.

[20]. Pariafsai, F. (2016d). Project-Based Simulation Games as Effective Tools in Education of Inexperienced Construction Students. Paper presented at the 3rd International Conference on Recent Innovations in Civil Engineering, Architecture and Urban Planning, Tehran, Iran, September 8th.

[21]. Pariafsai, F. (2016e). Strengths \& Weaknesses of a Project-Based Simulation Game as an Educational Tool.

[22]. Pariafsai, F. (2016f). Students' View on Potential of a Project-Based Simulation Game for Construction Education. International Journal of Scientific Research in Science, Engineering and Technology, 2(5), 514-523.

[23]. Pariafsai, F. (2016g). Virtual Project-Based Simulation Games: Effectiveness in Construction Education of Different Genders. Paper presented at the 4th International 
Conference on Modern Research in Civil Engineering, Architectural \& Urban Development, Barcelona, Spain, October 14th.

[24]. Pascarella, E. T., \& Smart, J. C. (1991). Impact of intercollegiate athletic participation for African American and Caucasian men: Some further evidence. Journal of college student development.

[25]. Pike, G. R., \& Graunke, S. S. (2015). Examining the effects of institutional and cohort characteristics on retention rates. Research in Higher Education, 56(2), 146-165.

[26]. Powell, B. A., Gilleland, D. S., \& Pearson, L. C. (2012). Expenditures, efficiency, and effectiveness in US undergraduate higher education: A national benchmark model. The Journal of Higher Education, 83(1), 102-127.

[27]. Raisman, N. (2009). Retain students retain budges: A how to. In.

[28]. Robbins, S., Allen, J., Casillas, A., Akamigbo, A., Saltonstall, M., Campbell, R., . . . Gore, P. (2009). Associations of resource and service utilization, risk level, and college outcomes. Research in Higher Education, 50(1), 101-118.

[29]. Ryan, J. F. (2004). The relationship between institutional expenditures and degree attainment at baccalaureate colleges. Research in Higher Education, 45(2), 97-114.

[30]. Schuette, S. (2019). A Comparative Study Analyzing Undergraduate Internship Participation and the Impact on Retention and Timely Degree Completion at a Four-Year, Private, Midwest Institution. Lindenwood University,

[31]. Smithson, M., \& Verkuilen, J. (2006). A better lemon squeezer? Maximum-likelihood regression with beta-distributed dependent variables. Psychological methods, 11(1), 54.

[32]. Swail, W. S. (2003). Retaining Minority Students in Higher Education: A Framework for Success. ASHE-ERIC Higher Education
Report. Jossey-Bass Higher and Adult Education Series: ERIC.

[33]. Turner, P., \& Thompson, E. (2014). College retention initiatives meeting the needs of millennial freshman students. College student journal, 48(1), 94-104.

[34]. U.S.DepartmentofEducation. (2020). College Scorecard. Retrieved from https://data.ed.gov/dataset/college-scorecardall-data-files-through-6-2020/resources

[35]. Upcraft, M. L. (1985). Residence halls and student activities. Increasing student retention: Effective programs and practices for reducing the dropout rate. San Francisco: Jossey-Bass.

[36]. Webber, D. A., \& Ehrenberg, R. G. (2010). Do expenditures other than instructional expenditures affect graduation and persistence rates in American higher education? Economics of Education Review, 29(6), 947-958.

[37]. Webster, A. L., \& Showers, V. E. (2011). Measuring predictors of student retention rates. American Journal of Economics and Business Administration, 3(2), 301-311.

[38]. Yorke, M., \& Longden, B. (2004). Retention and student success in higher education: McGrawHill Education (UK).

\section{Cite this article as :}

Sadjad Pariafsai, David Dalenberg, Christopher Ellison, Lucas Johnson, Fatemeh Pariafsai, "Association of Freshman Retention Rates with Instructional Expenditure and Residential Status : A Case Study for Large Public Colleges", International Journal of Scientific Research in Science, Engineering and Technology (IJSRSET), Online ISSN : 2394-4099, Print ISSN : 2395-1990, Volume 8 Issue 3, pp. 11-21, May-June 2021. Available at doi : https://doi.org/10.32628/IJSRSET2182100 Journal URL : https://ijsrset.com/IJSRSET2182100 